\title{
Optimalisasi Resolusi Konflik Agraria Antar Individu di Desa Sribatara Kecamatan Lasalimu Kabupaten Buton
}

\author{
Deson \\ Universitas Muhammadiyah Buton \\ Email: deson.desan90@gmail.com
}

\begin{abstract}
Abstrak, Konflik seringkali menimbulkan korban baik harta, benda bahkan jiwa. Desa Sribatara Kecamatan Lasalimu seringkali ditemui adanya konflik oleh karena tidak adanya titik temu antar pihak dalam penggunaan lahan. Mengingat kerugian yang dapat ditimbulkan di kemudian hari maka konflik harus ditangani dengan cepat. Penelitian ini bertujuan Untuk mengetahui peranan pemerintah Desa Sribatara dalam menyelesaikan konflik antar individu di Desa Sribatara Kecamatan Lasalimu Kabupaten Buton. Serta untuk mengetahui hambatan-hambatan yang diperoleh pemerintah desa dalam penyelesaian konflik antar individu di Desa Sribatara Kecamatan Lasalimu Kabupaten Buton.

Hasil penelitian ini menunjukan bahwa Peranan pemerintah desa sudah berjalan dengan baik sebagaimana mestinya sesuai dengan tugas dan fungsinya masing-masing. Meskipun penanganan dari pemerintah desa tersebut masih belum terselesaikan secara keseluruhan, akan tetapi dalam hal ini pemerintah desa suda berupayah dalam mengatasi konflik antar individu dengan beberapa tindakan yang dilakukan oleh pemerintah desa 1. Tindakan mengurai masalah, 2. Pemecahan masalah, 3. Penghapusan atau penghilangan masalah. Untuk menyesaikan konflik antar individu pemerintah desa melakukan proses Arbitrase, Mediasi dan Konsiliasi, dan upaya yang dilakukan menunjukan pola yang tepat dalam proses musyawarah.
\end{abstract}

Kata Kunci: Optimalisasi, Resolusi Konflik, Agraria 


\section{Pendahuluan}

Salah satu harapan dikeluarkannya Undang-undang Nomor 6 Tahun 2014, Tentang Pemerintah Desa yaitu meletakan dasar-dasar administrasi pemerintah desa sehingga para pemimpin formal (Kepala desa dan Perangkat desa), dan para Tokoh desa) semakin tahu dan mampu menjadi pelopor dalam masyarakat. Seperti halnya Desa Sribatara, berdasarkan pengamatan peneliti bahwa kepala desa bukan hanya sekedar sebagai pucuk pimpinan wilayah secara adminitrasi akan tetapi dipandang sebagai tokoh yang dianggap bertanggungjawab dan berkewajiban untuk mengurus dan menyesaikan persoalan yang ada didesa baik persolaan pernikahan, pesta panen, kematian, perselisian antar individu maupun persoalan hukum lainnya, pemerintah desa selalu dilibatkan oleh karenanya peranan pemerintah desa sangat penting dalam mewujudkan kesejahteraan masyarakat Desa Sribatara. Disamping itu Peranan pemerintah desa dalam menjalankan roda pemerintahan, pembangunan dan kemasyarakatan menjadi penentu keberhasilan, hal ini disebabkan pemerintah desa merupakan pemimpin penyelenggaraan pemerintah otonomi desa yang dipilih langsung oleh warganya.

Begitu pentingnya tanah bagi kesejahteraan manusia maka setiap orang akan berusaha memiliki dan menguasainya, adanya hal tersebut sering menyebabkan perselihan dan pertikaian antar sesama manusia serta menimbulkan perpecahan karena konflik agraria. Peristiwa yang terjadi di Desa Sribatara pada akhir tahun 2017 silam, disebabkan karena pemerintah desa belum cukup efektif untuk menangani konflik antar individu sehingga menyebabkan masalah berkepanjangan.

Sehubungan dengan konflik agraria yang meningkat setiap tahunnya maka diharapkan kerja keras dari setiap stakeholder terkait untuk dapat menekan angka konflik agraria. Fluktuasi konflik agraria Kabupaten Buton dalam 3 tahun terakhir dapat dilihat pada tabel 1 . 
Tabel 1.

Fluktuasi Konflik Antar Individu Desa Sribatara Tahun 2015 - 2017.

\begin{tabular}{|l|c|l|l|}
\hline No & Tahun & \multicolumn{1}{|c|}{ Nama yang Bertikai } & \multicolumn{1}{|c|}{$\begin{array}{c}\text { Jenis } \\
\text { Konflik }\end{array}$} \\
\hline & 2015 & Alwan dengan Wa Karimu & Konflik tanah \\
\hline & 2015 & La Ania dengan Wa Maana & Konflik tanah \\
\hline & 2016 & La Ania dengan Siti Syah & Konflik tanah \\
\hline & 2017 & Simudin dengan Ishak & \\
\hline & 2017 & La Mide dengan Gafar. S, S.P & Konflik tanah \\
\hline & 2017 & Ishak dengan Simudin & Konflik Sosial \\
\hline
\end{tabular}

Sumber Data: Data Konflik Desa Sribatara Tahun 2015- 2017

Dari data tersebut, konflik di Desa Sribatara didominasi oleh konflik antar individu yang berkaitan dengan pertanahan sedangkan yang lainnya konflik antar Pemerintah dan Masyarakat hal ini dimungkinkan disebabkan oleh beberapa hal diantaranya tidak jelasnya alas hak dalam kempemilikan lahan masyarakat dan peran pemerintah desa yang belum maksimal dalam penyelesaian konflik agraria serta program pemerintah dalam melakukan pensertifikatan lahan yang belum merata disetiap desa. di Kecamatan Lasalimu khususnya di Desa Sribatara.

Desa Sribatara juga ikut berperan mengemban tugas memfasilitasi pemungutan pajak bumi dan bangunan sehingga dalam hal ini konflik agraria yang berkepanjangan mengakibatkan masyarakat tidak membayar pajak sebagai kewajibannya yang merupakan sumber pendapatan bagi Negara

Kemudian mayoritas penduduk Desa Sribatara sumber mata pencahariannya adalah petani dengan terjadinya konflik tanah maka berdampak pada sumber pendapatan keluarga menurun baik dalam memenuhi kebutuhan hidup maupun dalam menyekolahkan anak-anak petani itu sendiri menjadi terhambat yang mengakitbatkan sebagian dari anak-anak tersebut tidak dapat melanjutkan pendidikan selanjutnya.

Di desa pada umumnya azas kekeluargaan masih sangat dijunjung tinggi, seperti halnya nilai-nilai kearifan lokal menumbuh kembangkan rasa persaudaraan yang tinggi dengan konflik ini maka terjadi renggangnya tali persaudaraan antar warga sehingga harmonisasi sosial masyarakat turut serta terpengaruh pula. Olehnya itu sangat penting kiranya peran Pemerintah Desa Sribatara untuk dapat menyelesaikan sengketa lahan ini dengan baik. hal ini sangat diharapkan oleh warga masyarakat Desa Sribatara dan dalam penyelesaiannya secara politik tidak merugikan pihak-pihak yang bertikai, secara 
agama tidak melanggar norma-norma yang ditetapkan oleh agama dan norma-norma budaya yang terdapat di Desa Sribatara serta secara ekonomi saling menguntungkan.

\section{Metode Penelitian}

Penelitian yang digunakan dalam penelitian ini adalah tipe penelitian deskriptif dengan pendekatan kualitatif. Teknik pengumpulan data melalui sampel menggunakan purposive sampling sebanyak 20 orang, yang diwawancarai mengenai relevansi yang diperlukan pada penelitian ini. Analisis data dilakukan menggunakan pendekatan kualitatif, yang berkaitan dengan peranan Pemerintah desa dan Hambata-hambatan yang diperoleh dalam penyelesaian konflik agraria antar invidu di Desa Sribatara.

\section{Pembahasan}

\section{A. Peranan Pemerintah Desa dalam Penanganan Konflik Antara Individu di Desa Sribatara Kecamatan Lasalimu, Kabupaten Buton.}

Peranan ada apabilah ada kedudukan, jadi peranan merupakan aspek yang dinamis dari status atau aspek fungsional dari kedudukan. Bila seseorang melaksanakan hak dan kewajibannya sesuai dengan kedudukannya, berarti orang tersebut telah menjalankan perannya. Jadi peranan yang dimaksud adalah tingkah laku yang diharapkan dari seseorang yang mempunyai kedudukan.

Pada dasarnya penyelesaian konflik yang perlu dilakukan oleh pemerintah desa dalam menyelesaikan konflik antar individu dapat dilakukan dengan beberapa pendekatan yakni:
a. Tindakan mengurai suatu masalah
b. Pemecahan
c. Penghapusan atau penghilangan masalah

Lebih lanjut dikatakan oleh Dahrendorf (2014: 21) bahwa resolusi konflik dilakukan dengan tiga pendekatan yakni:
a. Konsiliasi
b. Mediasi
c. Arbitrasi 


\section{Tindakan mengurai suatu masalah}

Pemerintah desa harus memahami konsep penyelesaian masalah dengan cara mengurai suatu persoalan yang selanjutnya menjadi tindakan yang solutif. Sejalan dengan tindakan tersebut, maka dibutuhkan kecakapan pemimpin dalam hal ini pemimpin dalam menyikapi sebuah persoalan. Pemimpin dituntut mampu mengurai persoalan, baik persoalan yang ringan hingga pada persoalan yang rumit tanpa harus menggerutukan kening. Artinya bahwa seorang pemimpin harus bersikap tenang dalam menghadapi persoalan, baik persoalan secara personal maupun antar individu masyarakat yang ada di desa.

Berdasarkan wawancara yang dilakukan dengan Tokoh masyakat (Ibrahim, S.S) menyatakan bahwa sejauh ini pemerintah Desa Sribatara sudah tanggap dalam menyelesaiakn persoalan, hal itu ditunjukkan dengan beberapa persoalan yang terjadi misalnya seperti perkelahian antara la Boni dengan La Simudin yang berakhir dengan cara perdamaian. (Hasil wawancara Ibrahim, S.S Tokoh masyarakat Desa Sribatara pada tanggal 10 september 2018).

Sejalan dengan apa yang disampaikan oleh ketua karang taruna Desa Sribatara yang menyebutkan bahwa pemerintah Desa Sribatara sejauh ini sudah menunjukkan sikap yang solutif dalam menyelesaikan konflik masyarakat Desa Sribatara yang terjadi sudah berjalan dengan cukup baik. Perna dulu perkelahian antara La boni dengan Simudin sudah sampai ditangan kepolisian, tetapi karena pemerintah desa masih mau menyelesaikan persoalan dengan cara kekeluargaan akhirnya pihak kepolisian hanya mengambil peran sebagai mediator dan selanjutnya kesepakatan berdamai juga terjadi dilingkungan desa. (hasil wawancara dengan ketua karang taruna Desa Sribatara, Safiudin, S,Pd.I pada tanggal 08 September 2018).

Sekretaris desa menceritakan secara singkat kejadian yang terjadi seperti konflik antara La Boni dengan Simudin. "sebenarnya persoalan itu tidak akan sampai ditangan kepolisian, hanya karena pihak keluarga yang merasa dirugikan langsung melapor ke kepolisian, sehingganya kepolisian mengambil sikap. Waktu kejadian itu, memmang pihak kepolisian bertepatan sedang berada dilokasi, sehingga pas keluarga mengetahui, secara cepat langsung ditangani oleh salah seorang anggota kepolisian yang tepat berada dilokasi waktu itu. Pemerintah desa waktu itu, khususnya saya selaku sekretaris Desa Sribatara meminta petunjuk kepada kepala desa terkait dengan persoalan itu. 
Kepala desa menyarankan agar pihak kepolisian harusnya jadi mediator saja. Sehingga ketika hal tersebut disampaiakn kepada salah seorang anggota kepolisian terkait permintaanpemerintah desa, maka persoalan itu diselesaikan di Desa Sribatara, dan kabar baiknya juga kedua belah pihak yang bertikai, baik kelompok keluarga ataupun individu yang tengah konflik dengan sadar menyatakan sikap untuk berdamai dengan membuat pernyataan dengan berisi poin-poin pernyataan yang berisi materai yang ditandatangani pelaku konflik dan beberapa saksi waktu itu. (wawancara dengan Sekretaris Desa Sribatara, Adi Kurniawan, S.H. Pada tanggan 08 September 2018).

Selanjutnya berdasarkan wawancara dengan Gafar. S. SP, terkait perihal persoalan sengketa lahannya dengan La Mide, menyatakan bahwa "Perselisihan Kami telah menemukan titik temu berdasarkan musyawarah keluarga yang dimediasi oleh Pemeritah desa, bersama Tokoh Masyakarat dan Tokoh Agama, dengan pengakuan bahwa memang lahan yang diperselisihkan tersebut adalah benar milik Gafar. S, SP. (Hasil wawancara Gafar. S, SP tanggal 12 september 2018 pihak terkait kasus sengketa lahan)

Sedangkan wawancara dengan La Ania tentang perselisihannya dengan Wa Maana tidak menemukan titik temu dikarenakan tingkat pendidikan yang rendah sulit menerima solusi untuk berdamai dari pemerintah desa sehingga masing-masing mengklaim miliknya meskipun pemerintah desa suda berupaya melakukan pendekatan Arbitrase, Mediasi dan Konsiliasi, La Ania menyatakan “ ohh,.. Lahan tersebut suda saya miliki sejak belum terbentuknya Desa Sribatara dan didalam lahan tersebut suda ada bukti yaitu ada beberapa pohon jati yang tumbuh disekitar lahan tersebut. (Hasil wawancara La Ania tanggal 13 september selaku pihak bertikai lahan)

Namun Wa Maana membantah tudingan La Ania dengan menyatakan "itu memang ada beberapa pohon jati disekitar kebun tersebut akan tetapi makanya ada jati disitu karena ada pohon jati yang perna saya tanam sehingga berkembang menjadi beberapa pohon jati jadi sebenarnya pohon jati itu bukan La Ania yang tanam tapi tumbuh dengan sendirinya. (Hasil wawancara Wa Maana pihak bertikai lahan pada tanggal 15 september 2018)

Berdasarkan beberapa keterangan yang disampaikan pada hasil wawancara tersebut, terlihat jelas bahwa pemerintah desa cukup siap dan tanggap terkait dengan persoalan yang terjadi antar individu, dengan menyelesaikan konflik secara damai 
tanpa harus tergessa-gesa menyerahkan kasus kepada pihak kepolisian, meskipun tidak semua konflik dapat diselesaikan seluruhnya ditingkat desa namun pemerintah desa suda cukup sigap dalam melaksanakan apa yang menjadi tugas dan tanggungjawabnya terhadap masyarakat Desa Sribatara.

Kasus lain yang bisa menjadi penjelasan terkait dengan kesiapan pemerintah desa dalam menyelesaikan konflik di desa terjadi ketika konflik yang terjadi antara La Angko dengan Wa Muuda yang terjadi pada bulan Januari 2017.

Sebagaimana yang diungkapkan oleh Sekretaris Desa Sribatara yang mengatakan bahwa "ketika konflik yang terjadi antara La Angko dengan Wa Muuda sebenarnya informasinya terlambat kami ketahui. Pemerintah desa mengetahui pasti persoalan itu ketika pihak kepolisian menyampaikan secara privasi kepada saya bahwa kasus itu sudah berlangsung selama 2 hari di kepolisian (polsek lasalimu). Jadi ketika saya mengetahui itu, segera saya kabari kepada kepala desa terkait informasi yang diperoleh dari pihak kepolisian. Jadi waktu itu kepala desa hanya meminta saya untuk meminta kejelasan kasus yang sudah sampai ditangan kepolisian. Saya selaku sekretaris desa waktu itu segera ke kepolisian untuk meminta informasi kepada kedua belah pihak melalui kepolisian saya dimediasi untuk memintanya. Setelah mengetahui pokok persoalan saya menelpon kepada Kepala Desa Sribatara untuk hadir di kantor polsek lasalimu. Waktu itu saya mengira kepala desa hanya datang sendiri, tetapi ketika itu saya melihatnya mereka datang secara berkelompok, kalau tidak salah ada sekitar 3-5 motor yang masuk ditaman polisi. Ternyata mereka merupakan saksi-saksi atau informan yang bisa memberikan keterangan pasti terkait dengan pokok persoalan. Kurang lebih 3 jam di kantor polisi (polsek lasalimu) kepala Desa Sribatara sudah bisa menyelasaikan konflik anatara La Angko dengan Wa Muuda dengan menyepakati beberapa poin pernyataan yang dibumbui materai enam ribu dan ditandatangani oleh pelaku komflik dan para saksi yang sudah dihadirkan. (hasil wawancara dengan Sekretaris Desa Sribatara, Adi Kurniawan, S.H. Pada tanggal 08 September 2018).

Sejalan dengan apa yang disampaikan oleh Tokoh Agama yang menceritakan kasus itu yakni: "waktu kasus yang terjadi anatara la Angko dengan Wa Muuda saya tidak tau persis pokok persoalanya, tetapi waktu itu sekitar pukul 11.00 wita kepala desa datang menginformasikan kepada saya. Waktu itu saya hanya menyebutkan beberapa nama yang bisa jadi sumber informasi untuk memperjelas persoalan itu. Jadi 
kasusnya la Angko dengan Wa Muuda itu persoalan tanah di Matana Mawi, begitu yang disampaikan bapak Udin Sukaria. Lebih lanjut beliau menceritakan setelah itu kepala desa meminta saya untuk bersiap-siap. Jelang beberapa waktu, kepala desa datang didepan rumah dan meminta saya untuk bersama-sama ke Kantor polisi (polsek lasalimu) untuk memberikan keterangan. (Wawancara dengan tokoh agama, Udin Sukaria pada tanggal 10 September 2018).

Masalah yang dihadapi oleh masyarakat Desa Sribatara hendaknya disikapi dengan kepala dingin oleh pimpinan, sehingga persoalan rumit sekalipun bisa diurai dengan tindakan-tindakan yang solutif. Berdasarkan hasil wawancara tersebut semakin memperkuat penjelasan bahwa pemerintah Desa Sribataracukup tanggap untuk menyelesaikan persoalan yang ada. Kekurangan yang bisa disimpulkan terkait pelaksanaan penyelesaian konflik oleh pemerintah Desa Sribatara terletak pada edukasi yang perlu dilakukan terhadap masyarakat untuk menyelesaikan konflik di desa terlebih dahulu sebelum di tangani oleh pihak kepolisian.

Pemerintah Desa Sribatara melakukan dua pendekatan pada persoalan yang sudah tergambar di atas, yakni konsiliasi, dimana pemerintah desa mengundang beberapa orang yang kompeten untuk saling memberikan pernyataan terkait penguatan-penguatan yang mereka harapkan lalu kemudian dicarikan solusinya. Arbitrase juga sudah tergambar pada hasil wawancara tersebut, dimana dari kedua persoalan yang diceritakan, baik oleh tokoh masyarakat, tokoh adat, sampai pada sekdes sebagai informan kunci sudah menunjukkan bahwa pemerintah desa menyelesaikan persoalan dengan cara bersepakat dengan penyelesaian persoalan secara berdamai atau saling memaafkan.

\section{Pemecahan Masalah}

Tindakan solutif yang mestinya dilakukan oleh pemerintah desa sebagaimana dijelaskan dalam teori Dahrendorf (2014: 21) bahwa resolusi konflik dilakukan dengan tiga pendekatan yakni Konsiliasi, Mediasi, Arbitrasi. Penyelesaian konflik yang dilakukan pemerintah Desa Sribatara bisa ditunjukkan dari hasil wawancara terhadap tokoh adat dan kepala dusun, serta sekdes sebagai informan kunci.

Wawancara yang dilakukan dengan tokoh adat Desa Sribatara menceritakan bahwa "pernah terjadi konflik antara Alwan dan Kariimu, jadi konflik ini awalnya terjadi 
karena lahan perkebunan yang dibuka oleh saudara Alwan diklaim sebagai lahan Wa Kariimu menurut pihak wa Kariimu. Waktu itu saya tau persis cerita sengketa itu yakni berdasarkan cerita sejara dari orang terdahulu memang tanah itu milik wa Kariimu. Ketika itu saya menjelaskan kepada kepala desa bahwa sebenarnya lahan yang sudah dibuka oleh saudara alwan memang milik wa Kariimu, jadi setelah mengetahui itu, kepala desa meminta pihak pertanahan untuk mencocokkan antara sertifikat tanah yang dimiliki wa Kariimu dengan kondisi real dilapangan. Jadi setelah dicek ternyata memang saudara Alwan mengambil sekitaran 5 meter tanah dari wa Kariimu. Setelah mengetahui kebenaran itu, kepala desa mengajukan permintaan kesediaan wa Kariimu untuk memberikan kesempatan kepada saudara Alwan melanjutkan pekerjaanya dengan catatan tanaman yang ditanami hanya tanaman jangka panjang dan tempo waktunya hanya dua kali tanam. Setelah wa Kariimu menyetujui, maka segera dipanggil tokoh adat, tokoh masyarakat, dan tokoh agama, waktu itu yang hadiri bapak Ambon (Udin Sukaria), La Imu (Ibrahim, S.S), dan beberapa saksi lain, termaksud saya sendiri, kalau dari luar Desa Sribatara hanya pegawai pertanahan dengan Babinkantibmas (Bripda Iwan), jadi ketika melakukan mediasi, kepala Desa Sribatara menunjukkan bukti-bukti yang ditemui dilapangan yg selanjutnya diperkuat oleh para saksi. Dan setelah melakukan negosiasi, maka saudara Alwan dan Wa Kariimu bersepakat dengan hasil kesepakatan saudara Alwan tetap menanam di kebun wa Kariimu dengan catatan hanya 2 kali menanam tanaman jangka pendek." (hasil wawancara dengan tokoh adat Desa Sribatara, la Bara pada tanggal 11 September 2018).

\section{Penghapusan atau penghilangan masalah}

Tindakan menghilangkan masalah dari sebuah persoalan merupakan hal yang perlu diketahui oleh semua pemimpin, baik dari kepemimpinan level tinggi sampai pada kepemimpinan dilevel terendah. Desa yang merupakan struktur pemerintahan politik terkecil dalam sebuah pemerintahan selalu dituntut untuk mampu menciptakan suasna pemerintahan yang kondusif dan proses kehidupan sosial yang steril dari masalah. Oleh karena itu pemerintah desa dituntut untuk mampu menciptakan lingkungan damai dan bersahaja.

Peranan pemerintah Desa Sribatara dalam menangani konflik antar individu dapat diketahui dari hasil wawancara pada beberapa informan, sebagaimana terkutip 
dalam wawancara yang dilaksanakan pada tanggal 11 September 2018 oleh Sekretaris Desa Sribatara menceritakan bahwa: "Untuk upaya yang dilakukan oleh pemerintah Desa Sribatara dalam mengangani konflik antar individu sejauh yang saya ketahui, sudah cukup baik, dimana dari beberapa kasus yang pernah terjadi di desa, tidak ada satu kasuspun yang sampai di meja hijau (pengadilan), kemudian ukuran yang paling nyata adalah sejauh ini tidak ada kasus yang sampai memakan waktu yang berkepanjangan, dan lebih lanjut tidak ada kasus yang sampai merengguk nyawa masyarakat yang saling bertikai. (wawancara yang dilakukan pada tanggal 11 Sptember 2018).

Pernyataan tersebut didukung oleh tokoh masyarakat Desa Sribatara yang menyebutkan kasus yang terjadi di Desa Sribatara: "Pernah satu waktu terjadi perkelahian antara La Simudin dengan Ishak di hari raya idul adha tahun 2017, ketika itu keduanya sama-sama mengkonsumsi minuman keras (alkohol), jadi perkelahian tidak terhindarkan, Ishak yang memang postur tubuhnya lebih kecil dari Simudin tentu tidak bisa kewalahan, sehingga pada saat terjadi perkelahian Ishak babak belur dan Simudin sedikitpun tidak mengalami cacat sedikitpun. Keesokan harinya, keduanya dipertemukan oleh tokoh masyarakat dan beberapa saksi lain, lalu Kepala Desa Sribatara saat itu hadir langsung menjadi mediator dari keduanya, sehingga perselisihan berakhir dengan perdamaian. Lihat sekarang, Ishak dengan Simudin tender proyek sama-sama di Waoleone, begitu keterangan yang disampaikan oleh Tokoh Masyarakata Desa Sribatara. (Wawancara pada tanggal 11 September 2018). Dari beberapa informan tersebut, terlihat bahwa pemerintah Desa Sribataramempunyai kemampuan untuk menyelesaikan konflik dengan menghilangkan masalah yang terjadi, sebagaimana tergambar pada kasus antara Simudin dan Ishak.

\section{b. Hambatan yang diperoleh Pemerintah Desa Dalam Menyelesaikan Konflik Antar Individu di Desa Sribatara Kecamatan Lasalimu, Kabupaten Buton.}

Faktor-faktor yang mempengaruhi peran pemerintah desa yaitu ada dua faktor utama yaitu faktor endogen dan faktor eksogen, yang mana dijelaskan bahwa faktor endogen merupakan penyebab yang dibawah individu sejak masih dalam kandungan hingga kelahiran, artinya bahwa hambatan yang terjadi karena faktor endogen lebih kepada kemampuan atau knowledge dari seorang pemimpin. Sedangkan faktor 
penghambat dari luar atau eksogen adalah faktor yang berasal dari luar diri individu (pemimpin) atau faktor yang bersumber dari pihak lain.

\section{Faktor Endogen}

Pemerintah Desa Sribatara telah berupaya untuk berperan aktif dalam setiap penyelesaian persoalan yang terjadi di Desa Sribatara. Berdasarkan hasil wawancara yang dilakukan terlihat bahwa pemerintah desa sudah mempunyai kesadaran untuk melakukan upaya dalam mengantisipasi konflik antar individu di Desa Sribatara, yakni dengan menyediakan regulasi dalam bentuk sangsi tegas kepada masyarakat yang melanggar, namun disisi lain, aturan-aturan itu belum terekspos dikalangan masyarakat secara luas, sehingga banyak masyarakat yang belum mengetahui aturan-aturan yang dibuat oleh pemerintah desa.

\section{Faktor Eksogen}

Dari faktor eksogen penyebab dari hambatan pemerintah desa dalam menyelesaikan konflik antar individu bisa dalam bentuk tingkat ekonomi, hubungan kekeluargaan, sampai pada pendidikan. Dari ketiga faktor tersebut, yang paling berpengaruh dalam menghambat pemerintah desa dalam menyelesaikan konflik adalah faktor pendidikan.

Faktor yang berpengaruh besar dari masyarakat adalah kurangnya masyarakat yang memahami tugas, fungsi dan tanggung jawab pemerintah desa dalam kehidupan bermasyarakat, sehingga banyak masyarakat yang mengalami konflik serta merta menyerahkan masalahnya di kepolisian tanpa melalui pemerintah desa.

Mencermari kondisi tersebut, dapat dijelaskn bahwa masyarakat belum mempunyai kesadaran untuk menyelesaikan persoalan dalam lingkungan bermasyarakat secara kekeluargaan. Pernyataan tersebut juga menunjukkan bahwa pemerintah desa belum dipercaya untuk menyelesaikan konflik yang terjadi di Desa Sribatara. 


\section{Kesimpulan}

Pemerintah Desa Sribatara sudah melakukan upaya dalam memecahkan masalah antara individu dengan beberapa pendekatan yakni; 1) Tindakan Mengurai Masalah; 2) Pemecahan Masalah; 3) Penghapusan atau Penghilangan Masalah. Sedangkan faktorfaktor yang menjadi penghambat dalam upaya pemerintah Desa Sribatara dalam menyelesaikan konflik antar individu terdiri dari dua faktor umum yaitu faktor endogen dan faktor eksogen.

\section{Daftar Pustaka}

Undang-Undang Nomor 6 Tahun 2014 Tentang Desa peraturan pemerintah Nomor 43 Tahun 2014 Tentang Aturan pelaksanaan Undang-undang Nomor 6 Tahun 20014 Tentang Desa

Adisa s, R. 2006, Pembangunan pedesaan dan perkotaan, Yogyakarta, Graha Ilmu, Cristuoulou. 2008 The secret of civil society, penerbit Gramedia.Jakarta.

Dahrendrof. 2014, Metode penelitian ilmu-ilmu sosial.Yogyakarta: Ull press Ndraha, Talidzu, 2014. Kybernology Ilmu Pemerintahan Baru. Jakarta: Rineka Cipta Jefri Herdiansyah, 2014 Permasalahan Abad 21: Sebua Sebua Agenda dalam Tuhuleley (Ed), 1993. Permasalahan Abad XXl, sebua agenda (kumpulan karangan). Yogyakarta: Sipress

Noeng Muhadjir, 1987 Organisasi dan Manajemen. Bandung: Alfabeta Soekamto, Soejono. 1982, Sosilogi Suatu Pengantar. Jakarta: Rajawali, press Susan. 2016 . Administrasi dan Managemen. Bandung: Amanah Ury. 2014. Pengantar Ilmu Pemerintahan. Bandung: Refika Aditama 